\title{
PERLINDUNGAN GOLPUT DALAM PERSPEKTIF HAM
}

\author{
Oleh:
}

\section{Ni Made Bakti ${ }^{1}$}

\begin{abstract}
The existence of non-voters in the election to get the pros and cons in the community. Most people support but some of the group refused. In this study discussed the How arethe implications ofabstentions in the democracy development in Indonesia? How is the human rights protection of the non-voters? This research is a normative legal materials sourced from primary and secondary legal materials. Legal materials collected qualitatively processed. Legal materials processing results are presented in descriptive analysis.

Abstentions implications in the development of democracy in Indonesia is a hallmark of democracy itself that is the freedom to argue. Not voting is a choice that must be respected in a democracy in Indonesia. Protection of human rights of non-voters must be done by the state, the law and every person as the option to be non-voters are part of the political rights of the born first-generation rights. Rights in the first generation is not ruled out. Society needs to see that non-voters is an option that must be respected in democratic life. Option to not choose (non-voters) should be defined as a human right in the legislation in Indonesia.
\end{abstract}

\section{Keywords: non-voters, human rights and democracy.}

\section{PENDAHULUAN \\ 1. LatarBelakang}

Pemilihan umum merupakan salah satu dari ciri-ciri negara hukum yang demokratis. Pemilihan umum menjadi sarana untuk mewujudkan pemerintahan dari rakyat, oleh rakyat dan untuk rakyat yang menjadi inti dari demokrasi. Menurut Jimly Ashiddiqie, konsep demokrasi dipraktikkan di seluruh dunia secara berbeda-beda dari satu negara ke negara lain. Setiap negara dan bahkan setiap orang menerapkan definisi dan

Mahasiswa Magister Ilmu Hukum Universitas

Udayana, Denpasar,Bali. Jl. Seroja Gg. Cerme No.1

Denpasar, e-mail : bakti.made@yahoo.com kriterianya sendiri-sendiri mengenai deokrasi itu. $^{2}$ Pemilihan umum secara demokratis di Indonesia diwujudkan dengan kesempatan bagi seluruh warga negara yang memenuhi syarat untuk memilih wakil-wakilnya di badan legislatif maupun memilih dari presiden dan wakil presiden hingga kepala daerah. Selain itu, apabila telah memenuhi syarat maka warga negara juga memiliki kesempatan yang sama untuk dipilih guna menjadi anggota legislatif atau menduduki kursi eksekutif.

JimlyAshiddiqie,2010,Konstitusi \& Konstitusionalisme Indonesia, Sinar Grafika, Jakarta, h. 116. 
Memilih dan dipilih adalah hak dari setiap warga negara. Hak ini bahkan dinyatakan sebagai hak asasi sebagaimana yang tercantuk dalam Pasal 43 Undangundang Nomor 39 Tahun 1999 tentang Hak Asasi Manusia menyatakan:

(1) Setiap warga negara berhak untuk dipilih dan memilih dalam pemilihan umum berdasarkan persamaan hak melalui pemungutan suara yang langsung, umum, bebas, rahasia, jujur dan adil sesuai dengan ketentuan peraturan perundang-undangan.

(2) Setiap warga negara berhak turut serta dalam pemerintahan dengan langsung atau dengan perantaraan wakil yang dipilihnya dengan bebas, menurut cara yang ditentukan dalam peraturan perundang-undangan.

(3) Setiap warga negara dapat diangkat dalam setiap jabatan pemerintahan.

Dalam pelaksanaan pemilu di Indonesia, masyarakat dihadapkan dengan fenomena golput atau golongan putih. Golongan ini adalah kelompok masyarakat yang tidak memilih. ${ }^{3}$ Keberadaan golput

Pengamat politik Centre for Electoral Reform (Cetro), Refli Harun, mengatakan ada tiga faktor yang menyebabkan penduduk Jakarta tidak tahu atau belum memutuskan pilihannya untuk memilih Gubernur DKI Jakarta. "Penyebabnya bisa karena kesadaran politik yang membuat dirinya enggan memilih, karena kesalahan teknis, atau karena masyarakat yang sudah apatis.

Penyebab pertama, ia menjelaskan, adalah karena banyak masyarakat yang menggunakan kata hatinya untuk menilai visi dan misi seorang calon gubernur. Refli mengatakan, saat kata hati masyarakat itu menyebutkan tidak ada calon gubernur yang cukup baik, maka saat itu juga masyarakat tidak menggunakan hak pilihnya. dalam pesta demokrasi ini dipandang secara pro dan kontra. Sebagian masyarakat menyetujui dengan berbagai alasan namun sebagian masyarakat menolak golput. Sikap ekstrim terhadap penolakan golput ditandai dengan Fatwa Majelis Ulama Indonesia (MUI) yang menyatakan golput haram. Situs MUI menerangkan bahwa fatwa dikeluarkan setelah melalui perbincangan hampir sehari penuh dalam rapat Komisi Masail Asasiyah Wathaniyah (Masalah Strategis Kebangsaan). Lalu, dikerucutkan dalam Tim Perumus dan diajukan ke sidang pleno Ijtima Ulama. Hasilnya, MUI menyatakan memilih pemimpin yang tidak memenuhi syarat-syarat sebagaimana disebutkan dalam butir 1 (satu) atau tidak memilih sama sekali padahal ada calon yang memenuhi syarat hukumnya adalah haram.

Fatwa tersebut mendapat tentangan dari berbagai elemen masyarakat. Hal ini disebabkan karena adanya pandangan masyarakat bahwa tidak memilih adalah hak asasi manusia ang wajib dilindungi dan dihormati oleh siapa pun. Sehingga penolakan terhadap golput dipandang sebagai

Untuk penyebab kedua, kata Refli, adalah karena kesalahan teknis dalam pencatatan daftar pemilih tetap. Ia menjelaskan, banyak masyarakat yang sebenarnya memiliki kartu tanda penduduk Jakarta namun tidak memiliki hak pilih karena tidak tercatat sebagai DPT. Kemungkinan karena masyarakat itu sendiri yang sengaja tidak mendaftarkan dirinya kembali atau karena dia memang tidak tahu bahwa dirinya tidak tercatat sebagai DPT.

\footnotetext{
"Dan bisa juga sebaliknya," kata Rafli. Bisa saja ada masyarakat yang tercatat memiliki KTP ganda dan menyebabkan dirinya termasuk DPT ganda. Namun saat pencoblosan, masyarakat itu hanya mencoblos satu kali. Sehingga seolah-olah ada DPT lain yang tidak mencoblos, padahal tidak ada.
} 
pelanggaran hak asasi manusia. Oleh karena itu sangat menarik untuk meneliti mengenai PERLINDUNGAN GOLPUT DALAM PERSPEKTIF HAM.

\section{Rumusan Masalah}

Rumusan masalah dalam penelitian ini meliputi:

a. Bagaimanakah implikasi golput dalam pembangunan demokrasi di Indonesia?

b. Bagaimanakah perlindungan HAM terhadap golput?

\section{Tujuan Penelitian}

Tujuan penelitian dalam tulisan ini terbagi menjadi tujuan umum dan tujuan khusus.

a. Tujuan Umum

Tujuan umum dalam penelitian ini adalah untuk mengetahui perlindungan terhadap golput dalam perspektif hak asasi manusia.

\section{b. Tujan khusus}

Tujuan khusus dalam penelitian ini adalah:

1) Untuk mengetahui implikasi golput dalam pembangunan demokrasi di Indonesia.

Sedangkan penyebab ketiga, menurut dia, adalah karena sikap apatis masyarakat. Refli mengatakan fenomoena tersebut memang banyak terjadi di tengah masyarakat di negara berkembang. Karena banyak masyarakat yang berpikir dia memilih atau tidak, tidak ada perbedaan yang akan ia rasakan. Masyarakat itu berpikir siapa pun gubernurnya, mereka tetap bekerja dan mendapatkan gaji seperti biasa.

Ketiga penyebab tersebut menurutnya masingmasing memiliki proporsi yang sama terhadap
2) Untuk mengetahui perlindungan HAM terhadap golput.

\section{METODE PENELITIAN}

Jenis penelitian dalam penelitian perlindungan terhadap golput dalam perspektif hak asasi manusia adalah penelitian yuridis normatif. Penelitian yuridis normatif ini mengkaji apakah golput diperbolehkan atau tidak dalam kehidupan berdemokrasi di Indonesia. Bahan hukum bersumber dari bahan hukum primer yakni peraturan perundang-undangan yang terkait dan buku-buku yang berkorelasi dengan pembahasan dalam tulisan ini. Bahan hukum dikumpulkan dengan sistem kartu. Setelah terkumpul, bahan hukum tersebut diolah secara kualitatif dimana hasil pengolahan tersebut disajikan secara desktiptif analisis.

\section{HASIL DAN PEMBAHASAN}

\section{Implikasi Golput Dalam Pembangunan Demokrasi di Indonesia}

Indonesia adalah salah satu negara di dunia yang menyelenggarakan pemerintahan dengan sistem demokrasi. Demos berarti "rakyat" dan cratein berarti "kekuasaan", dengan demikian kekuasaan berada di

kemungkinan penyebab terjadinya golongongan putih atau orang-orang yang tidak menggunakan hak pilihnya. Menurutnya, ketiga penyebab tersebut akan menyumbang masing-masing 10 persen pemilih golput.

Lebih lanjut baca Rafika Aulia, 2012, “3 Penyebab Kemungkinan Pemilih Golput”, Serial Online 2012, (Cited 2013 May. 2), available from: http://www. tempo.co/read/news/2012/07/08/228415500/3Penyebab-Kemungkinan-Pemilih-Golput 
tangan rakyat, dalam arti kekuasaan untuk, oleh dan dari rakyat banyak. ${ }^{4}$ Demokrasi di Indonesia bertumpu pada dasar fundamental negara yaitu Pancasila. Inu Kencana Syafiie dalam bukunya yang berjudul "Ilmu Politik" menyatakan Demokrasi lebih diharapkan agar terjadi kebebasan berkarya, kebebasan menampilkan kebolehan dan penemuan ilmiah, kebebasan pers, kebebasan berpendapat yang pada gilirannya cenderung melupakan dan mengabaikan pertimbangan moral. $^{5}$

Hukum selalu sarat dengan nilai-nilai tertentu. Apabila memulai berbicara tentang nilai-nilai, maka telah masuk pula kegiatan menilai dan memilih. ${ }^{6}$ Berpegang pada pendapattersebutmakademokrasidiharapkan selalu bertumpu pada pertimbangan moral.

Penyelenggaran pemilu merupakan salah satu wujud demokrasi. Penyaluran kedaulatan rakyat secara langsung (direct democracy) dilakukan dengan pemiihan umum, pemilihan presiden dan pelaksaan referendum untuk menyatakan persetujuan atau penolakan terhadap rencana perubahan atas pasal-pasal tertentu dalam Undangundang Dasar. Di samping itu, kedaulatan rakyat dapat pula disalurkan setiap waktu melalui pelaksanaan hak atas kebebasan berpendapat, hak atas kebebasan pers, hak atas kebebasan informasi, hak atas kebebasan berorganisasi dan berserikat seta hak-hak asasi lainnya yang dijamin dalam

Inu Kencana Syafiie, 2000, Ilmu Politik, Rineka Cipta Jakarta, h. 136.

Ibid.

Satjipto Rahardho, 2011, Penegakan Hukum Suatu Tinjauan Sosiologis, Genta Publishing, Jakarta, h. 137.
Undang-undang Dasar. ${ }^{7}$ Demokrasi akan selalu berkaitan dengan hak asasi manusia karena dua ciri dari negara demokrasi adalah partisipasi rakyat dalam pemerintahan yang diwujudkan melalui pemilu dan pengakua terhadap hak asasi manusia.

Prinsip dasar negara demokrasi selalu menuntut dan mengharuskan adanya pemencaran kekuasaan, agar kekuasaan tak terpusat di satu tangan. Kekuasaan yang berpusat di satu tangan bertentangan dengan prinsip demokrasi karena ia membuka peluang terjadinya kesewenang-wenangan dan korupsi. Dalil umum yang terkenal tentang ini adaah pernyataan Lord Acton bahwa "power tends to corrupt and absolute power corrupts absolutely" (kekuasaan itu cendrung korup dan kekuasaan absolutterpusat-korup secara absolut). ${ }^{8}$ Untuk mencegah pemusatan kekuasaan tersebut maka rakyat diharapkan berpartisipasi penuh dalam pemerintahan baik sebagai orangorang yang duduk di pemerintahan maupun orang-orang yang menentukan orang yang pantas duduk di pemerintahan khususnya pada cabang kekuasaan eksekutif dan pada cabang kekuasaan legislatif.

Penyelenggaraan pemilu tidak lepas dari berbagai fenomena dan permasalahan yang mengikutinya, salah satunya adalah golput. Golput bisa terjadi baik secara disengaja maupun tidak disengaja oleh pemilih. Golput yang dilakukan dengan sengaja adalah ketika pemilih dengan

Jimly Ashiddiqie, op.cit., h. 59.

Mahfud MD, 2010, Membangun Politik Hukum Menegakkan Konstitusi, RajaGrafido Persada, Jakarta, . h. 215 . 
sengaja tidak memilih dengan berbagai alasan. Golput yang dilakukan secara tidak sengaja adalah ketika pemilih yang berhak memilih tidak terdaftar dalam daftar pemilih tetap. Hal ini disebabkan karena kacaunya adaministrasi kependudukan.

Golput bagi sebagian orang dipandang sebagai cara untuk merusak tatanan pembangunan demokrasi. Dengan tidak memilih maka partisipasi rakyat dalam pemerintahan sebagaimana esensi dasar dari demokrasi tidak terlaksana secara optimal. Namun hal tersebut tidak selamanya benar. Tidak memilih adalah sebuah pilihan. Pilihan adalah bentuk dari pernyataan pendapat yang menjadi hak asasi sebagaimana diatur dalam perundang-undangan di Indonesia. Bahkan kebebasan berpendapat telah diakui secara internasional sebagai implikasi dari negara demokrasi. Oleh sebab itu justifikasi negatif atas golput merupakan pelanggaran terhadap hak asasi manusia.

Pro dan kontra tentang golput merupakan hal yang wajar sepanjang tidak menimbulkan hal-hal yang anarkis. Hal ini dipahami karena setiap elemen masyarakat memberikan sumbangan disintegrasi dan perubahan dan setiapmasyarakatberdasarkan pada paksaan yang dilakukan oleh suatu kelompok masyarakat kepada kelompok masyarakat lain. ${ }^{9}$

Perlakuan non diskriminatif terhadap golput merupakan upaya dalam mewujudkan keadilan. Kadilan adalah tujuan akhir dari sebuah sistem hukum, yang terkait erat

Astiwi, 2007, Sosiologi, Sinar Mandiri, Klaten, h. 4. dengan fungsi sitem hukum sebagau sarana untuk mendistribusikan dan memilihara suatu alokasi nilai-nilai dalam masyarakat, yang ditanamkan dengan suatu pandangan kebenaran, secara uum merujuk pada keadilan. ${ }^{10}$

\section{Perlindungan HAM Terhadap Golput}

Pada era keterbukaan sekarang ini isu HAM sering dijadikan sebagai alasan untuk menekan suatu negara bahkan mengucilkannya dari hubungan dengan negara-negara lain. Oleh karenanya penindasan HAM disuatu daerah tertentu di wilayah suatu negara akan menjadi bahan pembicaraan internasional bahkan untuk menetukan keputusan politik tertentu. Indonesia sebagai negara hukum juga telah mencantumkan penghargaan terhadap hakhak asasi tersebut sejak didirikannya negara ini. ${ }^{11}$

Diskursus mengenai hak asasi manusia adalah bagian penting dari negara hukum dengan sistem pemerintahan yang demokratis. Menurut Kartasaputra hakhak asasi/ hak-hak dasar adalah hak yang pokok atau dasar yang dimiliki manusia sebagai pembawaan sejak kelahirannya yang sangat berkaitan dengan martabat manusia tersebut. ${ }^{12}$ Perlindungan terhadap hak asasi manusia bukan hanya menjadi wacana dalam

10 Mucshin, 2004, Ikhtisar Materi Pokok Filsafat Hukum, STIH IBLAM, Jakarta, h. 83.

11 Endang Zaelani Sukaya et.al., 2002, Pendidikan Kewarganegaraan Untuk Perguruan Tinggi, Paradigma, Yogyakarta, h. 77.

12 Kartasaputra, 1987, Sistematika Hukum Tata Negara cetakan pertama, Bina Aksara, Jakarta, h. 246. 
tataran hukum nasional melainkan wacana dalam tataran hukum internasional. Secara teoretis, hak asasi manusia dibagi dalam dua jenis yakni:

a. Hak asasi individual yaitu hak atas hidup dan perkembangan hidup seperti hak atas kebebasan batin, hak atas nama baik, hak atas kebebasan beragama dan sebagainya. Hak-hak dasar ini disusun terutama demi perlindungan pribadi manusia terhadap kekuasaan negara.

b. Hak asasi sebagai makhluksosial yang dibagi dalam hak-hak ekonomis, social dan kultural. ${ }^{13}$

Hak asasi dalam menentukan pilihan pada pemilihan umum merupakan hak asasi individual. Pilihan sebagai golput merupakan hak asasi politik yang muncul sebagai HAM dalam generasi pertama. Generasi pertama, yakni perjuangan terhadap HAM sipil dan politik (civil and political rights). Perjuangan ini bermula pada abad ke-17 melalui teori-teori reformis yang dikonstruksikan oleh kaum liberalis di Eropa Barat. Konsep generasi pertama merupakan ide yang lahir dari harapan akan kebebasan dan perlindungan terhadap penyalahgunaan otoritas politik baik terhadap individu maupun dalam suatu komunitas. Hal inilah yang menjadi substansi pokok dalam konstitusi di hampir semua negara di dunia dan diadopsi oleh mayoritas kovenan dan deklarasi internasional sejak perang dunia II.

Abdul Ghofur Anshori, 2009, Filsafat Hukum, Gadjah Mada University Press, Yogyakarta, h. 112.
Generasi pertama ini lebih menempatkan hak asasi manusia dalam terminologi negatif (freedoms from) daripada sesuatu yang positif (rights to). Pemikiran mengenai konsepsi hak asasi manusia yang sejak lama berkembang dalam wacana para ilmuwan sejak era enlightenment di Eropa meningkat menjadi dokumen-dokumen hukum internasional yang resmi. Puncak perkembangan generasi pertama hak asasi manusia ini adalah pada peristiwa penandatanganan naskah Universal Declaration of Human Rights Perserikatan Bangsa-Bangsa pada tahun 1948 setelah sebelumnya ide-ide perlindungan hak asasi manusia itu tercantum dalam naskahnaskah bersejarah di beberapa negara, seperti di Inggris dengan Magna Charta dan Bill of Rights, di Amerika Serikat dengan Declaration of Indepen $\neg$ dence, dan di Perancis dengan Decla $\neg$ ration of Rights of Man and of the Citizens.

Dalam konsepsi generasi pertama ini elemen dasar dari hak asasi manusia mencakup soal prinsip integritas manusia, kebutuhan dasar manusia dan prinsip kebebasan sipil dan politik. HAM generasi pertama ini merupakan fundamental or basic right to life, liberty, personal security and phisical integrity yang secara resmi dikukuhkan dalam International Covenant on Civil and Political Rights. Dilihat dari tinjauan historis dan teoretis maka golput sebagai bagian dari hak politik tidak dapat dikesampingkan. Artinya hak asasi ini harus diupayakan untuk dipenuhi oleh negara. 
Pemenuhan HAM di Indonesia dilakukan berdasarkan Undang-undang Nomor 39 Tahun 1999 Tentang Hak Asasi Manusia yang merupakan penjabaran lebih lanjut dari nilai-nilai Pancasila. Pancasila sebagai dasar negara mengandung pemikiran bahwa manusia diciptakan oleh Tuhan Yang Maha Esa dengan menyandang dua aspek yakni, aspek individualitas (pribadi) dan aspek sosialitas (bermasyarakat). Oleh karena itu, kebebasan setiap orang dibatasi oleh hak asasi orang lain. Ini berarti bahwa setiap orang mengemban kewajiban mengakui dan menghormati hak asasi orang lain. Kewajiban ini juga berlaku bagi setiap organisasi pada tataran manapun, terutama negara dan pemerintah. Dengan demikian, negara dan pemerintah bertanggung jawab untuk menghormati, melindungi, membela, dan menjamin hak asasi manusia setiap warga negara dan penduduknya tanpa diskriminasi.

Pelindungan terhadap hak asasi bagi masyarakat yang memilih goput mutlak harus dilakukan ketika hidup di alam demokrasi.Masyarakat sebagai kebersamaan itu dibangun di atas basis kepercayaandan saling membutuhkan. Dalam pada itu, hukum (modern) dibangin di atas massa perundang-undangan prosedur, birokrasi dan sistem. Untuk menciptakan ketertiban dalam masyarakat, maka golput harus dihormati sebagai pilihan dan masyarakat harus menghormati pilihan tersebut meskipun mereka kurang sependapat atas pandangan tersebut.

\section{PENUTUP}

\section{Simpulan}

Berdasarkan uraian tentang kajian perlindungan golput dalam perspektif hak asasi manusia maka dapat disimpulkan halhal sebagai berikut:

a. Implikasi golput dalam pembangunan demokrasi di Indonesia merupakan ciri dari demokrasi itu sendiri yakni kebebasan untuk berpendapat. Tidak memilih dalam pemilu adalah sebuah piihan yang harus dihormati dalam kehidupan demokrasi di Indonesia.

b. Perlindungan HAM terhadap golput wajib dilakukan oleh negara, hukum dan setiap orang karena pilihan untuk menjadi golput merupakan bagian dari hak asasi politik yang terlahir dari generasi hak asasi pertama. Hak asasi pada generasi pertama ini adalah tidak dapat dikesampingkan.

\section{Saran}

Terkait dengan pembahasan yang telah diuraikan sebelumnya maka dapat disarankan beberapa rekomendasi yakni:

a. Masyarakat perlu memandang bahwa golput merupakan suatu pilihan yang wajib dihormati dalam kehidupan berdemokrasi.

b. Pilihan untuk tidak memilih (golput) sebaiknya ditegaskan sebagai hak asasi manusia dalam peraturan perundangundangan di Indonesia. 


\section{DAFTAR PUSTAKA}

\section{BUKU}

Abdul Ghofur Anshori, 2009, Filsafat Hukum, Gadjah Mada University Press, Yogyakarta.

Astiwi, 2007, Sosiologi, Sinar Mandiri, Klaten.

Endang Zaelani Sukaya et.al., 2002, Pendidikan Kewarganegaraan Untuk Perguruan Tinggi, Paradigma, Yogyakarta.

Inu Kencana Syafiie, 2000, Ilmu Politik, Rineka Cipta, Jakarta.

Jimly Ashiddiqie, 2010, Konstitusi \& Konstitusionalisme Indonesia, Sinar Grafika, Jakarta.

Kartasaputra, 1987, Sistematika Hukum Tata

Negara cetakan pertama, Bina Aksara, Jakarta.

Mahfud MD, 2010, Membangun Politik Hukum Menegakkan Konstitusi, Raja Grafido Persada, Jakarta

Mucshin, 2004, Ikhtisar Materi Pokok Filsafat Hukum, STIH IBLAM, Jakarta.

Satjipto Rahardho, 2011, Penegakan Hukum

Suatu Tinjauan Sosiologis, Genta Publishing, Jakarta.

Satjipto Rahardjo, 2009, Hukum dan Perilaku Hidup Baik Adalah Dasar Hukum yang Baik, Kompas, Jakarta.

\section{ARTIKEL ELEKTRONIK}

Rafika Aulia, 2012, “3 Penyebab Kemungkinan Pemilih Golput”, Serial Online 2012, (Cited 2013 May. 2), available from: http://www.tempo. co/read/news/2012/07/08/228415500 /3-Penyebab-Kemungkinan-PemilihGolput

\section{PERATURAN}

PERUNDANGUNDANGAN

Undang-undang Nomor 39 tahun 1999 tentang Hak Asasi Manusia. 